\title{
A New Concept for a Business Ethics Program and the Development of a Monitoring Method for the Engineering Ethics Environment of a Corporation
}

\author{
Yuji Okita Senior Member (Kanazawa Institute of Technology, yuji.okita@neptune.kanazawa-it.ac.jp ) \\ Kenichi Hayase Non-member (Central Research Institute of Electric Power Industry, hayase@criepi.denken.or.jp ) \\ Kyoko Oba Non-member (Kanazawa Institute of Technology, kyou@neptune.kanazawa-it.ac.jp ) \\ Jun Fudano Non-member (Kanazawa Institute of Technology, fudanoj1@neptune.kanazawa-it.ac.jp )
}

Keywords : business ethics, engineering ethics, ethics program, monitoring

For most modern corporations, engineering is an essential element. While the public increasingly demands social responsibility in business activities, the importance of the interweaving relationship between business ethics and engineering ethics is increasingly recognized. Nippon Keidanren (Japan Business Federation) urges its members to adhere to the Charter of Corporate Behavior and Global Environment Charter, in order to recover public confidence in businesses. The Institute of Electrical Engineers of Japan (IEEJ) revised its 1998 Code of Ethics in 2007, and at the same time published the newly authorized Standards for Conduct.

In this paper, firstly the change in the business environment is overviewed. Businesses generally operate under the premise that they are free to respond to market forces, but recently, although that is still an important premise, much more importance is placed on corporate social responsibilities. Since corporations are organizations which have pseudo-personalities, they should consider their role as the main constituent members of contemporary society. They should act honorably and respond to advances in society. Such a stance has become widely accepted.

Accordingly, a new approach for designing and implementing a business ethics program, named the EAB (Ethics Across the Business) approach, is proposed in this paper. The EAB method is easy for engineering oriented corporations to adopt in their business ethics programs because it derives from the process approach which has been much used by many corporations to perform such activities as quality assurance and environment management. EAB was devised referring to EAC (Ethics Across the Curriculum) in engineering education.

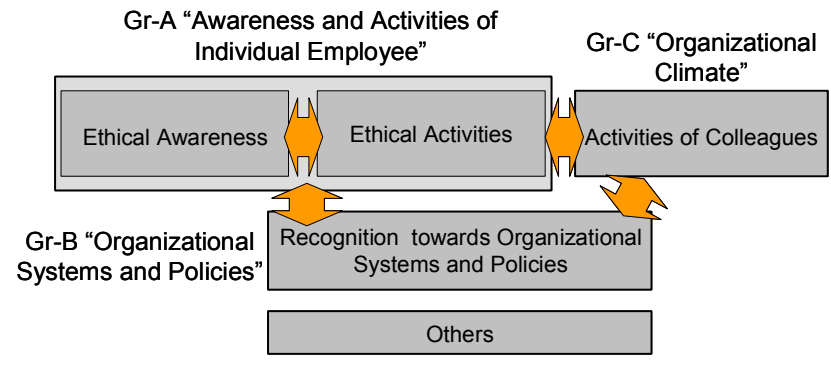

Fig. 1. Structure of the quetionnaire to employees

With the EAB method, social responsibilities (SRs) are taken into account as each significant business decision is made. When business ethics programs are independent of daily business activities, they not only cost more time and money to implement, but lead to poorer results. The EAB method can be realized by incorporating the requirements of SRs in the process approach, so that they become part of the PDCA (Plan-Do-Check-Act) cycle for each business activity.

Finally, a newly developed method for monitoring employee consciousness concerning engineering ethics is introduced together with trial results. It is important to monitor and evaluate the ethical consciousness of company personnel. The structure of the questionnaire developed for this purpose is shown in Fig. 1.

The questionnaire was used at three companies on a trial basis, as well as by WEB-based monitors. It was found that current ethical conditions could be identified and specific points needing improvement could be pinpointed using this system. 


\title{
企業倫理プログラムの新概念と実態把握手法の開発
}

\author{
上級会員 大来 雄二* 非会員 早瀬 賢一** \\ 非会員大場 恭子* 非会員 札野 順***
}

\section{A New Concept for a Business Ethics Program and the Development of a Monitoring Method for the Engineering Ethics Environment of a Corporation}

Yuji Okita*, Senior Member, Kenichi Hayase**, Non-member, Kyoko Oba*, Non-member, Jun Fudano***, Non-member

For most modern corporations, engineering is an essential element. While the public increasingly demands social responsibility in business activities, the importance of the interweaving relationship between business ethics and engineering ethics has been recognized. In this paper, firstly the change in the business environment is overviewed. Then, a new concept for designing and implementing a business ethics program, named the EAB (Ethics Across the Business) approach, is proposed. The EAB approach is highly adaptable for engineering-oriented corporations in their business ethics program activities because it derives from a process approach which has been much used by many companies to perform such activities as quality assurance and environment management. Finally, a newly developed method to monitor employee consciousness in terms of engineering ethics is introduced together with trial results.

キーワード : 企業倫理, 技術倫理, 倫理プログラム, アンケート, 技術者教育

Keywords : business ethics, engineering ethics, ethics program, monitoring, engineering education

\section{1. はじめに}

技術倫理・企業倫理に対する関心が高まっている。電気 学会は 2005 年に技術者倫理検討委員会を設置し, 1998 年に 制定した倫理綱領を改定するとともに，具体的な行動規範 を新たに制定公表した（2007 年）。また，有期限で設置した 上記委員会を, 理事会に直属する恒久的委員会としての倫 理委員会に改組した。日本学術会議は，2006 年に声明「科 学者の行動規範について」を発表した。また, 技術力をそ の存立基盤とする企業も，技術倫理の充実に取り組むよう になってきた。（社）日本経済団体連合会等でも，企業倫理 への取り組みが進められている。

このような状況の下で，各企業ではさまざまな取り組み がなされている。しかしながらそれは，次に述べるような 範囲にとどまっていることが多い。法令や社内規則の徹底

\footnotetext{
* 金沢工業大学 科学技術応用倫理研究所 (東京原宿研究所内) 干150-0001 東京都渋谷区神宮前 1-15-13

Kanazawa Institute of Technology

1-15-13, Jingumae, Shibuya-ku, Tokyo 150-0001

** (財) 電力中央研究所

干201-8511 狛江市岩戸北 2-11-1

Central Research Institute of Electric Power Industry

2-11-1, Iwadokita, Komae 201-8511

*** 金沢工業大学 科学技術応用倫理研究所

干921-8501 石川県石川郡野々市町扇が丘 7-1

Kanazawa Institute of Technology

7-1, Ohgigaoka, Nonoichi, Ishikawa 921-8501
}

遵守にだけこだわる狭い意味でのコンプライアンス活動, 倫理研修を社内のごく一部で実施してことたれりとする活 動, 社外に対して環境報告書的なものを広報することを中 心とした活動等である。経営理念, 倫理綱領等をかかげな がら，それだけにとどまっている場合もある。これらは企 業に属する人たちが, 実際に事業活動を展開する現場で, 倫理的に行動することを促すための具体的施策とは言い難 い。

本稿で, 筆者らは, 改めて企業が置かれている環境を技 術倫理と企業倫理の視点から分析する。その上で新しい企 業倫理活動の概念として, 事業活動に倫理を組み込んだ 「Ethics Across the Business」（以下 EAB とする）を提唱する。

また, 筆者らは, EAB 概念を実践に移すための企業倫理 プログラム・モデルを提示する。さらに, 企業の倫理的状 況を把握するために新たに開発した, 従業員意識調査アン ケートについて，試用結果を含めて詳説する。

\section{2. 企業が置かれている環境}

近代の企業は, 古典的自由主義と市場経済を基本として 活動してきた。しかし, 近年, 企業を取り巻く環境は, 社 会の公平性に関する関心の高まりや環境問題等の顕在化に よって, より企業の社会的責任を問う形に変化してきた。 企業は, 擬似的な人格を持つ組織体であるので, 現代社会 
の主要な構成員として，果たすべき役割を自らに問い，高 い「人格」を持つ存在として, 社会とともに発展してゆく 心゙きとの考え方が広く受け入れられるようになってきた。 本章では, この変化について考察する。

ちなみに，ここで「擬似的な人格を持つ組織体」との表 現を用いた。これは，狭義には，法人格を持つ会社とか財 団・社団法人等を指すことになり，その場合，任意団体と か個人商店的企業は含まれなくなるが，ここでは，営利を 求めるものであってかつ一般的に用いられている言葉とし て企業，企業倫理という用語を用いた。なお，営利を主目 的としない組織であっても本論文の考察は準用可能と筆者 らは考える。

$\langle 2 \cdot 1\rangle$ 企業と利潤追求企業は自己の利益を求め て, 財・サービスを市場に提供する。それが価格を含めて満 足できるものならば消費者は購入し, 企業は発展する。消 費者が購入しなければ, その財・サービスは市場から退出 し, 状況によっては企業そのものも倒産等の形で市場から 消えてゆく。このような形で，財・サービス，そして企業の 選別が市場によって行われ，公共の利益が実現される。こ の考え方は，自由主義社会に大きな経済成長をもたらした。 そして，科学技術の急速かつ意図的な進歩・適用が個々の 企業と市場経済の，いっそうの拡大を可能にした。

しかし，企業は社会・経済の発展をもたらす一方で，社 会的公正・健全に反する不祥事を生み出し続けてきた。国 際社会が複雑化し, 市場と企業が巨大化すると, これらの 不公正・不健全はともするとより見えにくくなり，露見し た段階では，すでに社会に大きな損失を与える状況を生む ようになってきた。

〈2·2〉事例の検討 次のような事例を想定してみよ う。ここに，高い技術力が必要な市場があるとする。そこ で， $\mathrm{A}$ 社と $\mathrm{B}$ 社が同じ製品分野の新製品 $\mathrm{X}$ の開発で, 激し く競っていたとする。

$\mathrm{A}$ 社は, 新製品 $\mathrm{X}$ の構成要素 $\mathrm{Y}$ を, $\mathrm{C}$ 社に下請けさせる ことにした。構成要素 $\mathrm{Y}$ の基本設計あるいは設計基準は, A 社から C 社に提示することになる。C 社も高い技術力を持 っているので，もし，A 社の基本設計あるいは設計基準に 誤りがあった場合には, $\mathrm{C}$ 社はそれに気づくべきだし, 気づ かずに製造してしまった場合の責任は C 社も負うとの趣旨 の契約を，両社は締結した。

$\mathrm{A}$ 社の開発は, $\mathrm{B}$ 社に数ヶ月のオーダーで先行していた。 しかし X の完成直前，A 社工場での試験時に，Y に重大な 欠陥があることが判明する。そのため $\mathrm{A}, \mathrm{C}$ 両社の技術者は, 連日善後策を協議する。しかし, 抜本対策を講じるには, 多額の費用と長い時間とが必要になる。市場での B 社に対 する優位を維持したいので，小手先の改修策を採用するこ とになる。採用された改修策の有効性を深刻に懸念し，意 見を表明する技術者は，A 社にも $\mathrm{C}$ 社にもいたが，その声 が経営トップには届かない。

改修策を施した X は，所管官庁の承認を得て市場に出さ れた。 $\mathrm{B}$ 社に対する数ヶ月先行のアドバンテージをフルに生
かして, A 社は, 次々に注文を獲得する。Xが実運用に供さ れる中, 重大事故につながりかねない事象も起きたが, そ れでも抜本策が講じられることはなかった。

しかし, 運用開始後 3 年も経たないうちに, 重大事故が 発生してしまう。

以上において次のように置き換えると, 実際にあった事 例になる(1)。

$\begin{array}{ll}\mathrm{A} \text { 社 } & \rightarrow \text { ダグラス社 } \\ \mathrm{B} \text { 社 } & \rightarrow \text { ロッキード社 }\end{array}$

新製品 $\mathrm{X} \rightarrow$ 乗客数 300 人規模のエアバス航空機 $(\mathrm{A}$ 社は DC10, B 社はトライスター)

構成要素 $\mathrm{Y} \rightarrow$ 航空機の胴体

$\mathrm{C}$ 社 $\rightarrow$ ダイナミックス社

A 社工場試験時に判明した重大欠陥 $\rightarrow$ 機体の地上 与圧テストで突然貨物室ドアが開き, 客室床が破壊 重大事故につながりかねない事象 $\rightarrow$ デトロイトで 離陸後まもなく貨物室ドアが脱落し, 操縦不能寸 前の状態になったが, 緊急着陸に成功（1972 年 6 月 12 日）

重大事故 $\rightarrow 1974$ 年 3 月 3 日にダグラス DC10 がパ リ郊外で墜落し, 乗客乗員 346 人全員が死亡。直接 原因は貨物室ドアのロック不完全によるドア脱落 この事故自体は 30 年以上経過しており, 古いものである。 しかし，A， B， C，X，Y等に別の固有名詞をあてはめれば 現在にも通用しそうであり, まさに過去の失敗を繰り返さ ないために，忘れてはならない事故である。

1970 年代は米国において技術者倫理教育および研究への 関心が高まり始めた時期である。前出の DC-10 の墜落事故 に加えて, 1972 年には, サンフランシスコ湾岸地域高速輸 送（BART）のコンピュータ制御プログラムの安全性に関す る内部告発があった。1970 年代中ごろには, フォード車の サブコンパクト・カー「ピント」の衝突時の燃料漏洩と火 災によって，多くの利用者が死亡した。これらは，当時技 術者倫理教育が重視されるようになるきっかけとなり, 現 在でも技術者倫理教育の教材として利用されている。

$\langle 2 \cdot 3\rangle$ 技術の社会性技術は, 社会を変える。技術 は本来社会の役に立つべきものである。その便益は, 多く の場合, 直接間接に企業の事業活動を通して, 社会にもた らされる。したがって, 企業の事業活動のあり方そのもの が技術が社会に与える影響に強く関係してくる。

もとよりわが国でも反社会的な企業行動は, 技術にだけ 関係しているわけではなく, 事実 1991 年に（社）経済団体 連合会がはじめて「経団連企業行動憲章」を制定したとき は, 証券, 金融業界の不祥事がきっかけであり, 技術的な ものではなかった。しかし, 1990 年代後半以降, 技術およ び技術を事業の中心にすえている企業が関わる不祥事が数 多く起きた。高速増殖炉「もんじゅ」のナトリウム漏洩事故, 東海村核燃料臨界事故, 自動車リコール事故隠し, 原子力 発電所定期点検データ改ざん等の事件により，一般の人々 の企業に対する不信感が高まった。 
例外はあるかもしれないが，企業は望んで反社会的行動 をとっているわけではない。ほとんどの企業は，法律に反 する行動を取らないこと，社内の諸規則を守ることなど， いわゆるコンプライアンス活動に注力してきた。これに個 人情報保護, 情報セキュリティ対策, 公益通報者保護（内 部告発者保護）等の動きも加わった。これらの動きは，本 来, そうあって然るべきことが求められるようになったと の側面はあるが，やり方によっては企業内の閉塞感を高め ることにもつながった(2)。

このような状況は, 企業が本来あるべき姿を考えさせる ことになった。（社）日本経済団体連合は 2004 年の憲章改 定に当って, 憲章の歴史的経緯に触れた後, 次のように述 べている。『そうした中で, 近年, 市民社会の成熟化に伴い, 商品の選別や企業の評価に際して「企業の社会的責任 (CSR: Corporate Social Responsibility)」への取り組みに注目す る人々が増えている。また, グローバル化の進展に伴い, 児童労働・強制労働を含む人権問題や貧困問題等に対して 世界的に関心が高まっており, 企業に対しても一層の取り 組みが期待されている。さらに, 情報化社会における個人 情報や顧客情報の適正な保護，少子高齢化に伴う多様な働 き手の確保等, 新たな課題も生まれている。企業は, こう した変化を先取りして, ステークホルダーとの対話を重ね つつ社会的責任を果たすことにより，社会における存在意 義を高めていかねばならない(3)。』

CSR やステークホルダーを重視する考え方は欧米のもの であるが，日本の商道徳や企業活動の理念等のなかにも共 通するものがある。いくつか例を示せば，「売手によし，買 手によし，世間によし」（近江商人の家訓）「正道を履み， 信義を重んじ堅実なるべし」(竹中工務店社是の第一項), 「所期奉公…社会のために貢献すること」（岩崎小彌太三綱 領の第一項)，「技術者達が技術することに喜びを感じ，そ の社会的使命を自覚して，思い切り働ける職場をこしらえ る」（東京通信工業 (ソニーの前身）の設立趣意書の第一項) 等がある(4)。

CSR やステークホルダーの重視はこれらに共通する考え であり，日本企業にとって取り入れやすいと思われる。事 実, 多くの企業で積極的な取組みが始められている。また, ISO（国際標準化機構）では，SR 規格（26000; 社会的責任 規格）の制定が進められており，近いうちに正式なものに なると予想されている。これは，企業だけでなく，社会的 な組織体全てを対象とする規格だが，日本で少なくとも企 業では，大きな違和感なく理解されるのではないか。

\section{3. 企業倫理の新概念とプロセス・アプローチ}

〈3·1〉歴史と事業環境を踏まえた企業倫理への取り組 み検討企業がおかれている環境を, 前章に述べたよう な形で認識したとする。そうすると, 次のステップはどの ようになるか。認識は認識として放置するのがその一つで あろう。また別のステップとして得られた認識を実際の企 業行動に反映しようとする努力があろう。
企業が信義を重視して社会に貢献することが正しい道と 考え, それを実現しようとするならば, 企業の日々の活動 自体が必然的に倫理的なものとなる。このような状態を筆 者らは, 企業の事業活動のいたるところで当事者が倫理性 を問い，これを認識した活動を自律的に行うという意味で $\mathrm{EAB}$ (Ethics Across the Business) と称することにし, 企業倫理 に取り組む企業の活動概念とすることを提唱した ${ }^{(5)}$ 。この EAB は工学教育の場での EAC (Ethics Across the Curriculum) を参考にして, 企業倫理への取組みを考察したものである。

〈3.2〉 EAC (Ethics Across the Curriculum) 科学技 術が社会に不可欠なものとなった現代において, 技術の便 益を拡大しつつ負の側面をいかに減らすかは大きな課題で ある。こうした中，技術者の行動によって引き起こされる 事故やトラブルをいかに減らすかの一環として，あるいは， 技術者自身が誇りを持って仕事を遂行するために，技術者 により良い行動を設計させる能力（デザイン能力）を身に つけさせる「技術者倫理教育」への関心が高まっている。

このことは, わが国における技術者倫理に関わる書籍の 出版が 1990 年代後半から急増していることからも, うかが い知ることができるが, 大学・工業高等専門学校等の教育 に関しては 1999 年に設立された日本技術者教育認定機構 (JABEE) が認定条件, すなわち認定のための審査判定を行 う認定基準(6)の中に, 技術者倫理を明記したことが大きなイ ンパクトとなった。JABEE は, 認定を求める教育プログラ ムが満たす心゙き要件の一つとして, 技術者倫理を学習・教 育目標に明記することを求めており, その結果, 多くの大 学が技術者倫理を単独の必修科目として, カリキュラムに 組み込むようになった。

このわが国における技術者倫理教育の状況に触れた文献 には，例えば筆者の一人札野（以下，札野と略）による技 術者倫理教育の必要性, 目的, 方法, 現状, 課題について 整理した論説 ${ }^{(7)}$ が挙げられる。この論説の中で, 札野はわが 国の技術者倫理教育が抱える三つの問題, 寸なわち(1)技術 者倫理とは何かという根本的な問いに対して, 明確な答え がわが国にはまだないこと, (2)すでに過密な工学系カリキ ユラムのどこに技術者倫理を入れるのかということ, (3)倫 理的判断能力をどのようにして測定し, 評価するのかとい うことを提示し, これらの解決の道を拓くものとして EAC を紹介している。

技術者倫理教育の目的は, 技術者により良い行動を設計 させる能力を身につけさせるものである。しかしながら， 技術者倫理を単独科目として学習した場合, 倫理を独立し た分野として扱うことから, 受講者も倫理を技術の実践と は別のものと認識してしまうことが少なくなく，得たもの と実践の場がうまく結びつきにくい。このような問題を解 決する方法として, 米国イリノイ工科大学専門職倫理セン ターが中心になって開発した教育課程全体を通して行う技 術者倫理教育が EAC である ${ }^{(8)}$ 。センターは, どのようにし て専門科目の中に倫理の要素を取り込むかの技法取得を目 的とした 7 日間のワークショップを, 1990 年以降毎年開催 
している。日本からも複数名が参加しており，参加者によ る報告もなされている(9)。

EAC は，技術者倫理に関する独立した科目の開講とは別 に，個々の専門科目の中に担当教員自らが倫理的要素を少 しずつ取り込む「マイクロインサーション」の実施によっ て, 可能となる。例えば電磁気学の中に生体への影響に関 する，自動制御理論の中に製品安全に関する話題や設問を 組み込む。この組み込みは僅かで構わない。それによって 期待される効果については，他の既存科目と対比しながら 考えると理解しやすい。数学の科目のひとつに「微分方程 式」がある。この「微分方程式」は工学を学ぶ者は基礎科 目として誰もが学習する。そして, この科目で学ぶ考え方 や計算方法はさまざまな専門科目で使われる。すなわち, 学習者はさまざまな科目で微分方程式を応用することによ って，その実践能力を獲得してゆく。このことと同じよう に，技術者倫理で学んだことを利用し応用する機会を，多 数の科目に分散配置することで, 学習者は技術者倫理の実 践能力を獲得することができる。

EAC の実践には，専門科目担当者の技術者倫理教育への 参画が不可欠であり, 教育プログラム全体での取り組みに よって成り立つ。前述した札野の提示したわが国の技術者 倫理教育が抱える三つの問題も，(1) 教育プログラム全体 で教育することから，技術者倫理教育についての根本議論

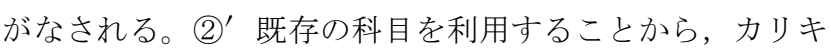
ユラムに大きな変更を加えなくてよい。(3) 教育プログラ ム全体として技術者倫理を教えることから，入学時と卒業 時の倫理能力の測定等も比較的に容易に行うことができる ことにより，解決が可能になる。

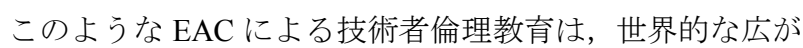
りを見せている。日本でも金沢工業大学が（独）科学技術 振興機構社会技術研究公募型プログラム「Ethics Crossroads の形成と科学技術倫理の構築」（2004 年度～2007 年度）の 一環として，3 日間に短縮した日本版 EAC ワークショップ を, 2005 年から 3 年に渡り毎年開催した。その第 1 回には イリノイ工科大学での取り組みの中心人物であるマイケ ル・ディビス氏を招いて指導を受けた ${ }^{(10)}$ 。3 年間のワークシ ヨップの参加者合計は 100 名を超え, 日本での EAC の取り 組みに大きな役割を果たしたといえよう。同大学は引き続 き文部科学省「平成 19 年度 特色ある大学教育支援プログ ラム (特色 GP)」（2007 年〜）の中で，初年次教育から専門 教育全体に展開された技術者倫理教育プログラム, すなわ ち EAC を展開している。また特色 GP の一環として 2009 年 3 月 11 日に開催された第 1 回国際シンポジウム「教育課程 全体を通した技術者倫理教育の展望」では，米国を中心と した他国の講演者から，EAC の取り組みの紹介があった。 米国では 1999 年に EAC 学会 (Society of Ethics Across the Curriculum) ${ }^{(11)}$ が設立され，年次大会を開催する等の活発な 活動を展開していること, すでに世界の複数の大学におい てEACが実践されていること等, EACの現状が紹介された。
存立の目的があり，目的を達成しようとして事業を展開す る。したがって, 事業活動は企業にとって本来的な活動で あり，それは役員や社員にとって「やる」ものであって，「や らされる」ものではないことが望ましい。

では，倫理活動はどうか。企業の目的に沿った本来的な 活動なのか。それとも外部からの強制によって「やらされ る」ものであって, 「やらざるを得ない状況になるまではや りたくない」ものなのか。筆者らはそれを本来的なやるべき 活動ととらえている。学校教育において, 微分方程式が単 に卒業に必要な単位を得るための数学科目の一つとして, カリキュラムの中で教えられ学ばれるのかといえば，そう ではない。専門科目の要所要所でそれが再登場し, 学ぶも のが実際の応用能力を獲得していくように, 企業倫理は本 来の事業活動の要所要所で確認し, 実践していくべきもの である。第 1 章で述べた「古い概念」のような形で実践す るのではなく, 本来の事業活動に組み込んで実践するべき ものである。人は主体的, 自律的にことに取り組むとき, 大きな成果を出す。やらされ感を持ちながらでは大きな成 果は出ない。経済学の歴史 ${ }^{(12)}$ が教えることに対比するなら ば, 農業の分野において, 小作農が農地改革によって自営 農化することによって農作業に対して主体性, 自律性を持 ち，農業生産性が飛躍的に向上したように，企業倫理は， 全ての役員や社員が日々の事業活動の中で主体的, 自律的 に取り組むように動機付けていくことによって, 事業活動 の生産性向上につなげていくべきものである。企業倫理は 事業活動の全ての局面に組み込まれ, 主体的, 自律的に実 施されることが望ましい。すなわち EAB が望ましい。その 姿を従来の取り組み方と対比する形で, イメージ的に Fig. 1 に示す。図の(a)従来の取り組みでは, 企業の全体を統括す る組織 (HQ) 内に企業倫理の担当者が置かれ, またそれぞ れの部門 (Division) にも担当者が置かれている。企業倫理 統括担当は部門担当に計画策定などの指示を出し, 報告を 求める。部門担当は求めに応じて書類を作成し, あるいは 会議などに出席する。それは往々にして形式的なものにな りやすく, 部門側は受動的になりやすい。また担当者以外 の者の企業倫理意識も希薄なものになりがちである。総じ て部門側では, 関係者が「やらされ感」を持ちやすい取り 組み形態である。図の(b)EAB による取り組みでは, 事業活 動そのものの中に企業倫理活動を組み込むことを目指寸の で, 業務上の指示, 命令系統, 報告・連絡・相談系統がそ のまま生きる。それに加えて教育とか情報共有のネットワ 一クが整備され, 組織図に表されないコミュニケーション が活発に行われる。なお(a)と同様に, 何からの意味で企業 全体や部門の活動を, 統括推進する役割を持つ者 (Assigned ethics person) の配置も必要となるが, それは図示していない。

では, 全ての事業の局面を通して行う倫理活動とは, 具 体的にどのようなものになるか。企業には, その存在目的・ 理念があり，それを実現するために事業計画を立て，推進 し，業績を評価し，問題点があれば改善策を講じている。 $\mathrm{EAB}$ の実際を企業経営の視点と対比する形で示したものが 
Table 1 である。

新製品・新サービスの開発であれ，品質向上活動であれ， その他の活動であれ, 事業に必要な活動をマネジメント・シ ステムととらえ, システム全体は入力と処理と出力を持つ 複数のプロセスが組み合わさったものとしてとらえること ができる。いわゆるプロセス・アプローチであり，その代表 的なものが Plan-Do-Check-Act (PDCA) のサイクルでとらえ る取り組み方である。

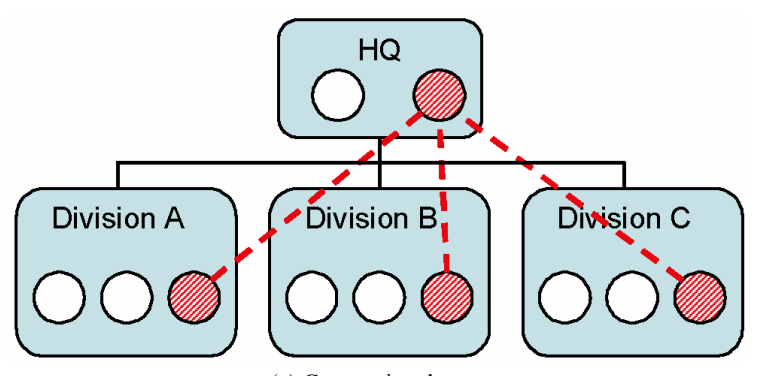

(a) Conventional type

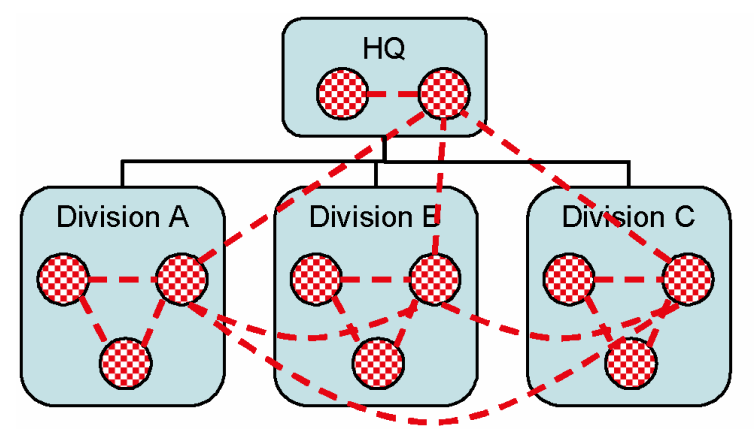

(b) EAB type

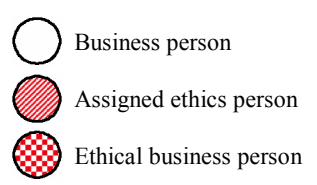

Fig. 1. Business ethics promotion by conventional type and EAB type.
企業における倫理マネジメント・システムでも, PDCA サ イクルの適用を前提とした具体モデルを構築することがで きる。例えば，新製品開発の中で新材料の適用を計画する 段階で, 直接的な材料コスト, 加工性, 実現できる製品性 能等とともに，ありえる使用条件下での安全性，解体性， 廃棄に伴う諸問題等の検討も計画の中に組み込む。それら の諸問題に対して, 開発途上に限らず, 市場に投入した後 でも状況をモニターし, 必要に応じて改善策を講じるかを 検討する。検討に基づいて実行し, 実行結果を評価し, 評 価結果に基づく改善を実施し, 次の計画策定につなげる。 このような PDCA サイクルを回すことが可能である。そし てこのことは可能なばかりか重要である。なぜなら, 新し く開発された技術は，その時点では社会で実際に適用され たことはないからである。それは人の利便性を向上するた め開発されたものであろうが，その適用によって，人，そ して社会が実際にどのように反応するかの実績は, 最初は 皆無である。したがって, 細心の注意と最大の関心を持っ て, その反応を見守る必要がある。PDCA サイクルを回すこ とが重要とされる所以である。

このような倫理マネジメント・システムに関し, 計画内容 及び具体的に展開するべき施策, 推進組織等の全体を倫理 プログラムと呼ぶ。EAB による倫理プログラムの構成要素 には，どのようなものがあるであろうか。倫理プログラム の構成要素については, 日本では麗澤大学企業倫理研究セ ンター, 経営倫理実践研究センター, 電力中央研究所等が, また, 米国では Ethics \& Compliance Officer Association や Ethics Resource Center 等の先行研究があり，それらを集約す ると次の 13 項目を挙げることができる ${ }^{(13)}$ 。

(1) 倫理方針（経営理念, CSR 憲章, 倫理綱領等)

(2) トップのコミットメント

(3) 倫理担当

（4）実施計画の策定（リスクの特定・対応方策等）

(5) コミュニケーション

Table 1. Business management and the viewpoints of EAB (Ethics Across the Business).

\begin{tabular}{|c|c|}
\hline $\begin{array}{c}\text { Business management viewpoints } \\
\text { (企業経営の視点) }\end{array}$ & EAB program viewpoints（EABによるプログラムからの視点） \\
\hline $\begin{array}{l}\text { Visualization of a corporation's raison } \\
\text { d'etre（企業の存在目的を明示しているか） }\end{array}$ & $\begin{array}{l}\text { Does it contain CSR (Corporate Social Responsibility)?/ Does it contain ethical viewpoints?/ } \\
\text { Does it visualize values and code of judgement on which corporation relys? (企業の社会的 } \\
\text { 責任(CSR)を果たすものになつているか／倫理の視点が含まれているか／重視する価値, 判 } \\
\text { 断基準が明示されているか) }\end{array}$ \\
\hline $\begin{array}{l}\text { PLAN: Visualization of business conduct } \\
\text { standards and business plan (事業行動指 } \\
\text { 針, 事業計画を明示しているか) }\end{array}$ & $\begin{array}{l}\text { Are the concrete CSR proceding plans developed?/ Are the concrete plans to realize } \\
\text { corporation relying values developed?/ Are the assessment based improvement action plans } \\
\text { contained? (CSRを果たす具体的手段が明確になつているか/重視する価値を実現するため } \\
\text { の具体的手段が明確になつているか/評価結果に基づく改善策を織り込んでいるか) }\end{array}$ \\
\hline $\begin{array}{l}\text { DO: Execution of business plan (事業計画 } \\
\text { を実行しているか) }\end{array}$ & $\begin{array}{l}\text { Are above mentioned concrete plans adopted through the business execution?/ Is the } \\
\text { related eduation and training program executed? (上記手段を事業計画の実行過程で適用し } \\
\text { ているか /上記手段についての教育·研修が行われているか) }\end{array}$ \\
\hline $\begin{array}{l}\text { CHECK: Assessment of the results of } \\
\text { business plan (事業計画の実行結果を評価 } \\
\text { しているか) }\end{array}$ & $\begin{array}{l}\text { Are the executed results gathered, assessed and evaluatged? (上記手段の教育·研修実績, } \\
\text { 適用実績のデータを把握, 分析, 評価しているか) }\end{array}$ \\
\hline $\begin{array}{l}\text { ACT: Improvement actions based on the } \\
\text { assessment (評価結果に基づく改善を実施 } \\
\text { しているか) }\end{array}$ & $\begin{array}{l}\text { Are the improvement plans based on the above evaluation classified into either immediate } \\
\text { and next cycle action plans? / Are the immediate improvement plans actually executed? (上 } \\
\text { 記手段の評価結果に基づく改善策を分類し, 直ちに実施するべきものと次のPDCAサイクル } \\
\text { の計画に盛り込むべきものに分類し, 直ちに実施するべき改善策を実施しているか) }\end{array}$ \\
\hline
\end{tabular}



(6) 教育·研修
(7) 相談空口・ヘルプライン
(8) 緊急時対応
(9) 広報
(10) モニタリング
(11) 監査
(12) 経営層による見直し
(13) 継続的改善

全く新たに企業倫理プログラムを構築する場合には，方 針の策定から始めることになる。しかし，一般的に経営理 念・事業目的の類は，定款に明記する等の形で企業はすでに 持っている。また，多くの企業は，昨今の環境の変化を踏 まえて, 企業倫理に関わる何らかの施策を展開していると 思われる。このような場合に, 何から始め, どのように検 討を進めてゆくべきであろうか。

検討の基本は実態の把握である。トップのリーダシップ でやるべきことを決めて推進するとの形もあろうが，まず は企業倫理プログラムの現状がどの程度充実したものであ るか, 企業活動の最前線にいる従業員の倫理的意識が現在 どうなっているか, その両者を把握し, 弱点改善の施策を 計画し，展開する。そして展開施策の効果をモニタリング し,さらに，改善を図ってゆくのが手順である。

プログラムの現状は，倫理活動の担当者が一人でもいれ ば，教育活動とか社内広報活動の実績等の形で，責任者に 報告されるだろう。ところがそのようにして報告された「現 状」が，最前線の従業員の意識や行動を反映したものであ るかは，そのままではわからない。わからないままにして おいては，プログラムの効果的推進は望めない。実態を把 握する一つの方法として，アンケート調査がある。ここで は，筆者らが開発した従業員意識調査について，章を改め てさらに考察する。

\section{4. 従業員意識調査による実態把握}

〈4・1〉 意識調査アンケートの概略構成 筆者等は, 企業倫理にかかわる従業員の意識・行動と認識を把握する ための従業員意識調査アンケートを開発した ${ }^{(14)}$ 。設問の視
点は，三つある。従業員が自分自身の倫理意識と倫理行動 をどのように考えているか (A 群), 会社の倫理活動をどの ように認識しているか (B 群), 職場の仲間の倫理行動をど のように見ているか（C 群）がそれである（Fig. 2 参照）。 これらについてアンケートし, 現状を定量的にとらえるも ので, 全 91 問で構成した。回答は， 7 件法 (「1. 全くあて はまらない」〜「7. 非常によく当てはまる」）で求める形式 とした。

A 群の設問は, 同一の課題に対する意識と行動を一対の 設問として, アンケートすることによって，意識と行動の 実態とその乘離状況を把握できるようになっている。B 群 は, 従業員個人の意識と行動に影響があると想定される組 織（企業）の体制・施策をアンケートするものである。C 群 は, A 群と同一の課題に対して, 同じ職場の仲間の行動が アンケート回答者にどのように写っているかを問うもの で, 職場風土把握の参考にすることを目的した。また，こ れらの群に含まれない若干の設問をその他の設問として用 意した。

個人の意識・行動を問う $\mathrm{A}$ 群では, 次の項目 (小群)ごとに いくつかの設問を用意した。設問は，同じ主題について， 意識を問うものと行動を問うものの対で構成した。

$\mathrm{A} 1$ : 法令・契約等遵守への意識・行動

A2 : 社会の安全・健康・福祉への意識・行動

A3 : 客観的・自律的判断の意識・行動

A4 : コミュニケーションへの意識・行動

A5 : 専門能力・教育研修への意識・行動

A6 : 仕事への誇り・意欲

組織の制度・施策に対する認識を問う $\mathrm{B}$ 群の設問は, 次の小 群から構成した。

$\mathrm{B} 1$ : 倫理方針の浸透への認識

B2：方針・活動の整合性への認識

B3 : 組織トップの姿勢への認識

B4 : 倫理コミュニケーションへの組織的取り組みの認識

B5 : 倫理活動の推進体制への認識

同じ職場の仲間の行動がアンケート回答者にどのように映 っているかを問うことによって, 職場風土の把握をねらっ

Gr-A "Awareness and Activities of Individual Employee”（個人の意識-行動）

\section{Gr-C "Organizational Climate"（組織風土）}

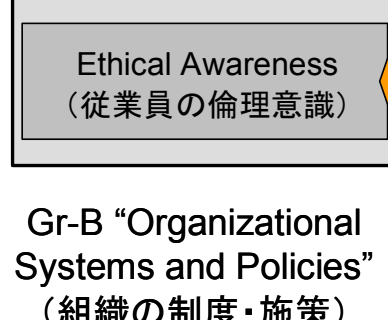

Ethical Activities （従業員の倫理行動）

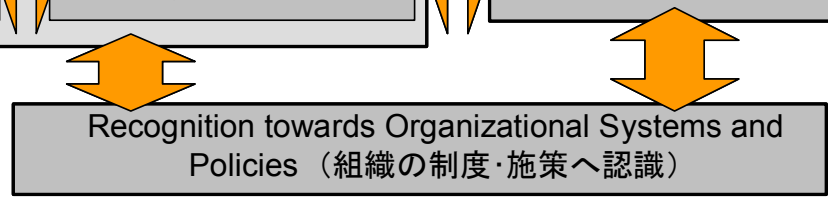

Others（その他の設問）

Fig. 2. The structure of the employee questionnaire 
た C 群の設問は, 次の小群から構成した。

$\mathrm{C} 1$ : 法令・契約等遵守の状況認識

$\mathrm{C} 2$ : 社会の安全・健康・福祉の状況認識

$\mathrm{C} 3$ : 客観的·自律的判断の状況認識

$\mathrm{C} 4$ : コミュニケーションの状況認識

C5 : 専門能力·教育研修の状況認識

Fig. 2 にはこれらの設問群の関係も示してある。

またアンケート調査票の冒頭で回答者の属性として，年 齢, 勤続年数, 職位, 部門, 主な業務についての回答を求 めた。

〈4·2〉 アンケート結果 従業員意識調査アンケート は，試行に協力した製造業 3 社に対して実施した。また, 比較対象の基礎データを得ることを目的に WEB 上でも実 施した。

WEB 調査は，専門会社に委託し，まず同社の保有する首 都圏 $30 \mathrm{~km}$ 以内で無作為に抽出されたモニターのうち, 18 歳〜59 歳かつインターネット上で回答可能なモニター 10,069 名に, アンケート調査対象者を選定するためのスク リーニング調查を依頼した。スクリーニング調查への回答 者 3,874 名のうちから, 以下の条件に該当した 435 名に対し て，実際のアンケートを実施した。

・雇用形態 : 正社員

-職位 : 課長クラス以上, 係長クラス, 主任クラス, 一 般職

・業種 : 建設業, 製造業, 電気・ガス·熱供給・水道業, 情 報通信業, 運輸業

- 職種 : 技術系職種

アンケート調査は, 2007 年 8 月に実施し, 334 名（回収 率 77.8\%）からの回答を得た。分析の前処理として, 同じ 選択肢に回答が $80 \%$ 以上集中しているサンプルを棄却し，

残った 325 名（有効回答率 74.7\%）を有効サンプルとした。 企業アンケート 3 社は, いずれも製造業なので, 325 名の WEB 調査のうち, 製造業だけを抽出した。その結果 117 名 が分析対象となった。

ここで, 企業アンケートに協力した製造業 3 社を A 社, B 社， $\mathrm{C}$ 社と呼ぶことにする。 3 社の空口担当には，技術系職 種を対象として，アンケート実施を依頼した。調查は 2007 年 7 月〜2008 年 1 月に実施し, A 社, B 社, C 社から 168 名, 50 名, 50 名の回答が得られた。分析前処理（同じ選択 肢に回答が $80 \%$ 以上集中しているサンプルの㶳却, 全体で $5 \%$ 欠損值のあるサンプルの萧却，欠損值への各設問の平均 值の補填）を行った結果，それぞれから 157 名，50 名，46 名の有効サンプルが得られ, 分析対象とした。これらの分 析対象について, 次の五つの方法で分析を行った。

方法 1: WEB 調查製造業の平均值・標準偏差との比較

方法 2: 調查企業データの内での平均值と各属性との比較

方法 $3:$ 意識と行動の乘離分析

方法 4 : 職場の皆の行動と自分の行動の差の分析

方法 5 : 各分類及びその他の設問と意識・行動との相関分 析
方法 1 による結果の例を Fig. 3 に示す。前述のように設問 数は 91 あるが, 群, 小群に分けてある。その分類にしたが って, A, B, C 社の回答傾向を平均值 (Fig. 3 (a)) と標準偏差 (Fig. 3 (b)) について WEB 調査製造業の值との差分を求めて 示してある。

この図から次のようなことが言えよう。

(a) A， B， C 社とも WEB 調査製造業に比べて平均值が 高く, 標準偏差が小さい傾向を示している。平均值が高い ことは, この 3 社の従業員は (アンケート回答者の範囲で), WEB 調査製造業に比べて, 優れた企業倫理が醸成されてい ることを示している。また標準偏差が小さいことは, 単一 企業では意識・状況認識のばらつきが小さくなることを示 している。

(b) A, B, C 社とも WEB 調査製造業に比べて, A C 群 の中でも特に $\mathrm{B}$ 群（組織の制度・施策）で, 平均值がより高 くなる傾向を示している。これは会社としての企業倫理活 動への取組みが WEB 調査製造業より充実していることを 示している。

(c) A， B， C 社を個別に見ると， A 社は全ての項目で B 社より平均值が高く, $\mathrm{B}$ 社はほとんど全ての項目で $\mathrm{C}$ 社よ り高い。標準偏差では, 平均值ほどのはっきりした傾向は 示されないが，それでも A， B，Cの順で標準偏差が大きく なる。これは, 各社の企業倫理活動への取り組みの差を示 している可能性がある。ちなみに, 今回の調査は, 各社の 全従業員を対象とする悉皆調査ではなく, アンケート回答 者選定にあたってのランダム性（回答者がどれだけ母集団 をどれだけ代表しているといえるか）も不十分と思われる ので,この推論は妥当でない可能性もある。

また，方法 5 による相関分析の一部として, 従業員の意 識と行動を対で質問した A 群の小群ごとに, 意識と行動の 関係性を, 相関係数を算出して評価した。その結果, 法令・ 契約等遵守 (A1 小群) と社会の安全·健康・福祉（A2 小群） では，WEB 調査製造業はそれぞれ $0.76,0.75$ と強い相関が 観測されたのに対して，A， B， C 社とも若干低めの（中程 度の）相関が観測された。

客観的・自律的判断 (A3 小群), コミュニケーション（A4 小群）では，一般に A， B，C社のほうが WEB 調査製造業 に対して意識と行動について高い相関を示したが，その程 度はばらついた。

専門能力・教育研修（A5 小群）では, WEB 調査製造業, $\mathrm{A}, \mathrm{B}, \mathrm{C}$ 社とも意識と行動の相関は中程度であったが, 後 者は全社に対して, 相対的に相関が小さかった。

〈4·3〉 改善活動の着眼点 以上に示した全体的な傾 向にくわえて, 各社のデータを個別に分析し, また, 設問 群だけでなく個々の設問への回答を詳細に分析すると, 企 業倫理活動改善のための着眼点が具体的に見えてくる。Fig. 3 に示した会社毎, アンケート設問小群毎の傾向の元には, 個々のアンケート設問に対する回答データがある。例えば, 方法 1 の分析で, 個別設問「会社トップは倫理に積極的に 取り組んでいる」に対して, アンケート回答の平均值が基 


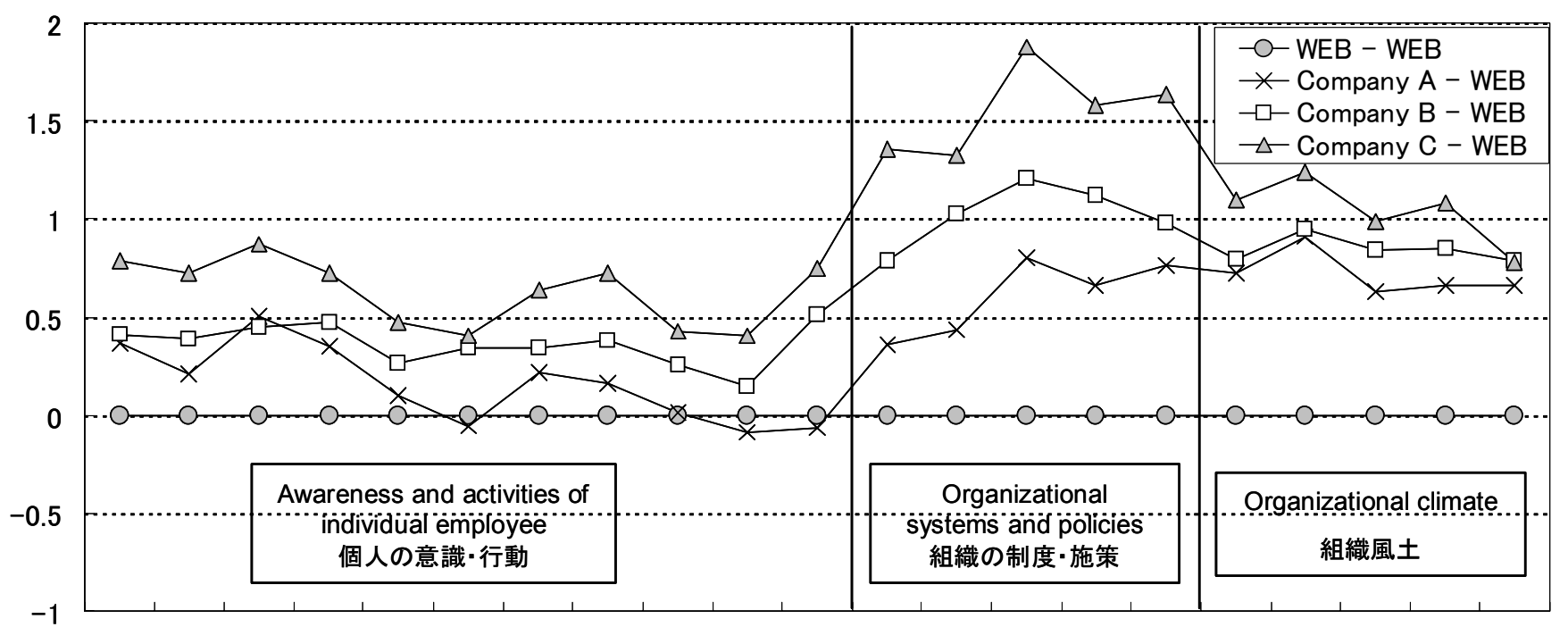

$\begin{array}{llllllllllllllllllllllllllll}\text { A1a } & \text { A1b } & \text { A2a } & \text { A2b } & \text { A3a } & \text { A3b } & \text { A4a } & \text { A4b } & \text { A5a } & \text { A5b } & \text { A6 } & \text { B1 } & \text { B2 } & \text { B3 } & \text { B4 } & \text { B5 } & \text { C1 } & \text { C2 } & \text { C3 } & \text { C4 } & \text { C5 }\end{array}$

(a) Difference with the average value of the WEB based investigation data on manufacturing companies （WEB 調査製造業の平均值との差分）

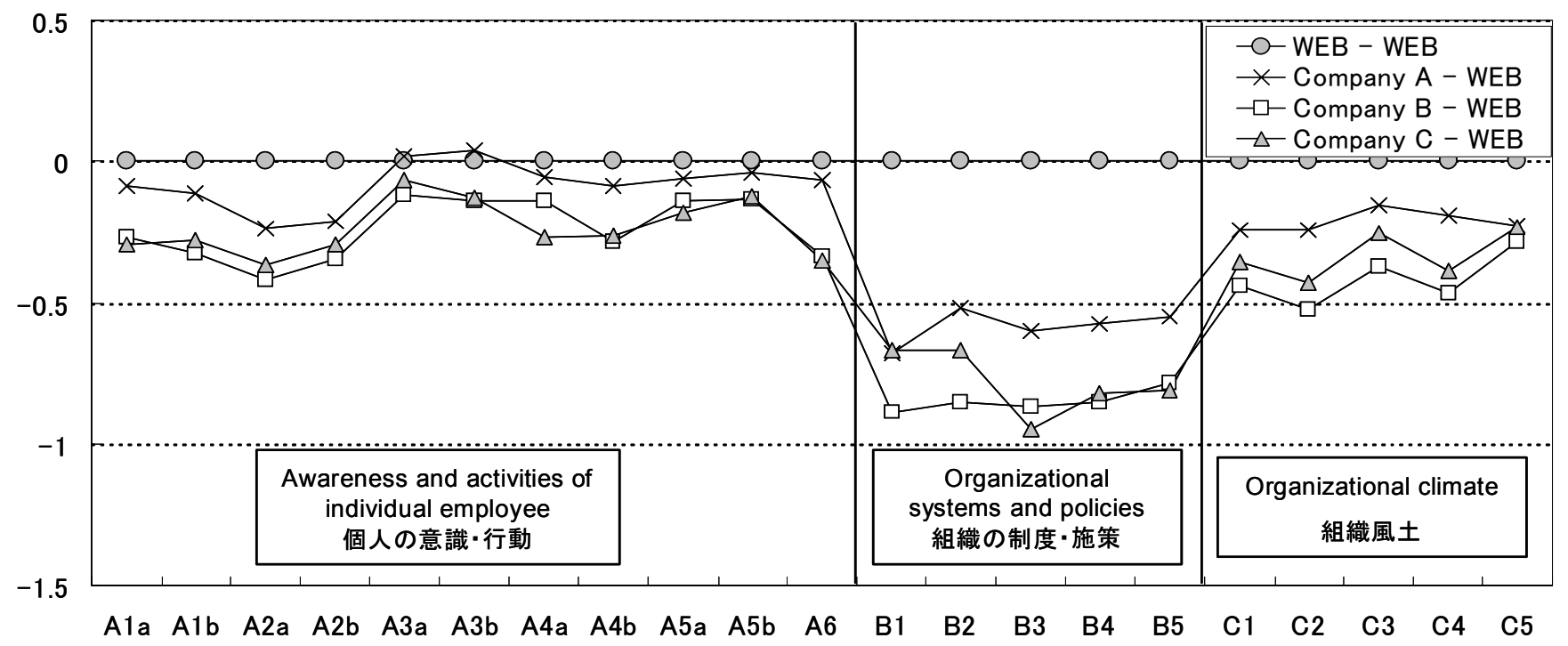

(b) Difference with the standard deviation of the WEB based investigation data on manufacturing companies（WEB 調査製造業の標準偏差との差分）

A1a Awareness for compliance with laws and agreements Alb Activities to ensure compliance with laws and agreements A2a Awareness for social safety, health and welfare A2b Activities to ensure social safety, health and welfare A3a Awareness for objective and autonomous judgment A3b Activities to ensure objective and autonomous judgment A4a Awareness for communication

$\mathrm{A} 4 \mathrm{~b}$ Activities to ensure communication

A5a Awareness for professional expertise and educational training

A5b Activities to ensure professional expertise and educational training

A6 Pride and morale in work

B1 Recognition towards dispersion of ethical policies

B2 Recognition towards coordination between policies and activities

B3 Recognition towards commitment as top management of organization

B4 Recognition towards systematic approach to ethical communication

B5 Recognition towards systemizing promotion of ethical activities

C1 Recognition of status of compliance with laws and agreements

C2 Recognition of social safety, health and welfare status

C3 Recognition of objective and autonomous judgment status

C4 Recognition of communication status

C5 Recognition of professional expertise and educational training status

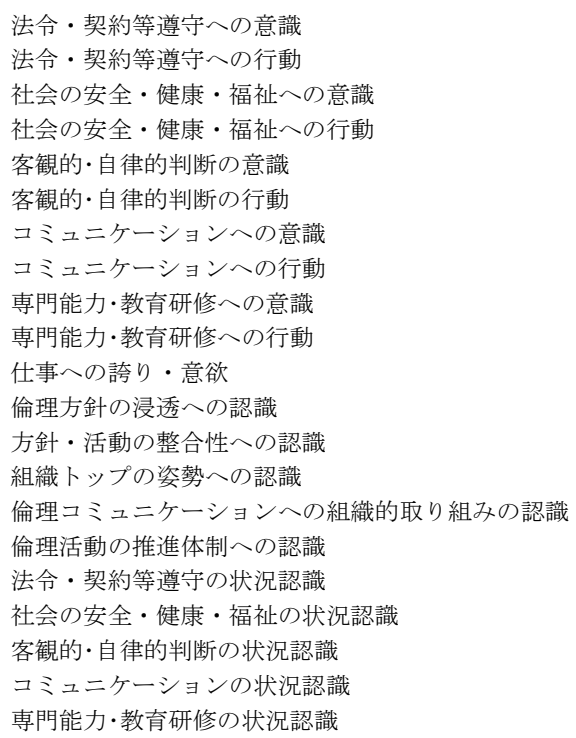

Fig. 3. Tendency to employee consciousness of the A,B,C companies (referenced to the WEB based investigation data on manufacturing companies). 
準值（Fig. 3 では WEB データを基準值にしてある）に対し て高い值を示しているにもかかわらず，個別設問「私の職 場では，倫理担当部署や倫理担当者は積極的に活動してい る」に対する回答がそれほど高くない場合があったとする。 もし，その会社では，倫理担当部署や倫理担当者を置いて いるとすれば，その活動のあり方に改善の余地があるので はないかということが，容易に予想できる。そのデータを 担当部署に提示し, 実情を確認することにより, 活動のあ り方を改善したほうがよいかどうかがよりはっきりと見え てくる。

また, 方法 5 の分析で, 組織の制度・施策（B 群）に関す る質問小群の回答と, 個人の意識・行動（A 群）に対する 質問小群の回答の間の, 相関係数を算出した結果, 例えば, 「倫理方針の浸透への認識（B1）」と「社会の安全・健康 · 福祉への意識・行動 $(\mathrm{A} 2) 」 の$ 相関係数がある会社では高く, 別の会社では低かったとする。後者では, 前者に比較して 製品安全に関わる技術者の行動が十分かを確認することに より，改善が図れる可能性が高いと言えよう。

方法 2 の分析のように, 同一社内のアンケート回答デー タであっても, それを属性毎に, 例えば, 部門毎（設計, 品質保証，製造等）や役職毎に集計して比較することによ って，いろいろな改善活動の着眼点が見えてくる。

これらを総合して今回のアンケートの分析で得られた着 眼点は，例えば，次のようなものである。

(a) トップの企業倫理活動の姿勢が従業員に強く認識さ れているだろうか。

(b) トップの姿勢と職場リーダの姿勢との間にずれがな いだろらか。

(c) 企業倫理活動を推進している組織の活動が従業員か ら見えているだろうか。

(d) 個人の倫理行動の強化をどのような点から図るべき か。この点を具体的に補足すると，対応関係がある設問間 で一般に回答の平均值は「自己の倫理意識 $>$ 自己の倫理行 動 $>$ 職場の仲間の行動」の傾向を示すが, 自己の倫理行動 と職場の仲間の行動の間の不等号が反対側を向いている場 合には, その項目について個人倫理行動強化の必要性を検 討してみる価值があると考える。

(e) 企業倫理活動が活動のための活動, 担当業務から遊 離した取組みになっていないだろうか。

(f) 上長の指示には無条件に従わざるを得ないといった 雰囲気がないだろうか。

（g）技術者が自分の能力（自分にできることできないこ と）を把握して仕事をしているだろうか。また，専門能力 の向上に励んでいるだろうか。

(h) 不正行為の社内チェック機能についての認識が十分 だろうか。

アンケート実施企業では，これらの着眼点をよりどころ にして, 実施中の企業倫理・技術者倫理活動の内容を確認 し，改善を実施することができよう。そして，それを次期 の活動計画策定につなげ, 改善のループを回し続けること
ができよう。企業倫理活動の充実を図ろうとしている企業 は企業倫理プログラムの PDCA サイクルをまわそうとする とき, この従業員アンケートはそのためのきっかけとして 使うこともできよう。

\section{5. おわりに}

企業を取り巻く環境とその環境に対応するための企業施 策は, 変化しつつある。それに伴い, 企業倫理施策も大き く変化している。従来は, 法律違反とか企業イメージ毁損 のリスクを極力小さくすることが施策の中心だった。

しかし，それらのいわば受動的な施策だけでなく, 企業 が長期的に社会に受け入れられる存在になるための, いわ ば能動的な施策を展開して, 事業の継続的な発展をめざす ようになってきている。この変化は, 必然的にコンプライ アンス, 企業倫理, CSR 活動の高度化を企業に要請する。

本研究は, そのような企業活動の一助とするために, 企 業倫理プログラム・モデルの確立を目指して行ったもので ある。本研究の成果として, EAB と呼ぶ概念の提示, 概念 を実現する手段としてのプロセス・アプローチの具体モデ ル, 実態把握のための従業員意識調査アンケートを中心と するツール開発等がある。今後さらに研究を進め, 実態把 握の精度, モデルの有効度の向上, 新たなツール開発等を 行ってゆく予定である。

\section{謝 辞}

本研究は，(独）科学技術振興機構社会技術研究開発事業 の助成を受け, 平成 16 年度公募型プログラムの一つとして 実施した研究課題「Ethics Crossroads の形成と科学技術倫理 の構築」で得られた知見をベースとし, 継承発展させたも のである。関係諸氏に感謝する。また, 論文作成過程でご 指導ご鞭撻いただいた諸氏にも感謝する。その指摘事項の 多くは的確なものであり, 本論文内容の改善に役立った。

(平成 21 年 4 月 25 日受付, 平成 21 年 12 月 24 日再受付)

\section{文献}

(1) 柳田邦男:「失速 - 事故の視角」, 文芸春秋, pp.129-176, 文春文庫 (1981-7)

（2）「そして, 会社も壊れる」，日経ビジネス, 2006 年 5 月 1 日号, pp.40-43 (2006)

(3) http://www.keidanren.or.jp/japanese/policy/cgcb/charter.html

(4) T. Yashiro, J. Fudano, S. Itakura, and K. Oba : An Innovative Engineering Ethics Management System for Responsible Corporate Governance, pp.83-85, University of Tokyo Press (2005) (in Japanese)

野城智也・札野 順・板倉周一郎・大場恭子 : 実践のための技術倫 理, pp.83-85, 東京大学出版会 $(2005-10)$

(5) 研究成果報告書 : 「Ethics Crossroads の形成と科学技術倫理の構築」, pp.125-170, (独) 科学技術振興機構社会技術研究開発事業・公募型プ ログラム (2004-2007)

(6) URL : http://www.jabee.org/OpenHomePage/kijun/criteria2010_081112 090123.pdf（この文書は現時点（2009 年 4 月）で最新の認定基準だ が, 技術者倫理に関する規定は認定審査が開始された 2001 年から認 定基準に入っている)

（7）札野順:「技術者倫理教育, その必要性, 目的, 方法, 現状, 課題」, 工学教育, Vol.54, No.1, pp.16-23 (2006-1)（ちな夕にこの「工学教育」 は技術者倫理教育に関する特集号である。30 編近い論説, 論文が収 録されており, この時点での日本の技術者教育への取り組みがよく 
分かる)

(8) M. Davis : Ethics and Engineering Curriculum, pp.111-142, Ethics and University, Routledge (1999)

(9) 例えば, M. Davis : Ethics and the University, Routledge, pp.111-142 (1999)

H. Nishimura : "Meanings and Possibilities of Engineering Ethics Education Across the Curriculum", Japanese Society for Science and Technology Studies, Proc., pp.189-190 (2003-11) (in Japanese) 西村秀雄 : 「全教育課程を通して行う技術者倫理教育の意義と可能 性」, 科学技術社会論学会年次研究大会, pp.189-190 (2003-11)

(10) 研究成果報告書:「Ethics Crossroads の形成と科学技術倫理の構築」, pp.78-124, (独) 科学技術振興機構社会技術研究開発事業・公募型プ ログラム (2004-2007)

(11) URL : http://www.rit.edu/cla/ethics/seac/index.html

(12) 猪木武徳：「戦後世界経済史」, 中公新書, 中央公論新社 (2009-5)

(13) 研究成果報告書 : 「Ethics Crossroads の形成と科学技術倫理の構築」, p. 144, (独) 科学技術振興機構社会技術研究開発事業・公募型プログ ラム (2004-2007)

(14) K. Hayase, K. Oba, Y. Okita, A. Motoki, Y. Okabe, and J. Fudano : "Development of Engineer Questionnaire for the Business Ethics Program Model", Japan Society for Business Ethics Study, Proc. (2007-10) (in Japanese)

早瀬賢一・大場恭子・大来雄二・本木女や子・岡部幸徳・札野 順 : 「企業倫理プログラムモデル構築のための技術系従業員アンケート の開発」, 日本経営倫理学会研究発表 (2007-10)

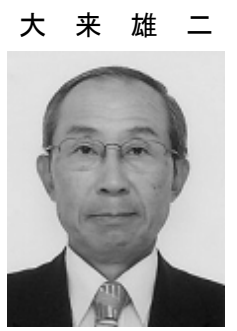

（上級会員） 1946 年生。1969 年東京大学工学 部電気工学科卒業。1975 年米国マサチュセッツ 工科大学大学院修士課程修了 (EE\&CS)。1969 年東京芝浦電気 (株) 入社。主として電力用保 護継電器およびシステムの開発設計に従事。そ の他技術企画，知的財産等の業務に従事。2000 年東芝総合人材開発（株）に入社し，技術者教 育に従事。2006 2008 年日本技術者教育認定機 構 (JABEE)。2006 年より 金沢工業大学客員教授, 現在に至る。IEEJ プロフェッショナル。
早 瀬 賢 - (非会員) 1975 年生。2000 年京都大学総合人

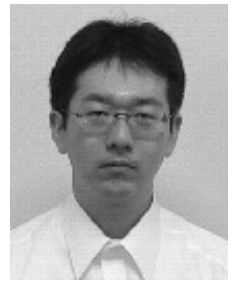
間学部基礎科学科卒業。2002 年同大学大学院工 ネルギー科学研究科エネルギー社会・環境科学 専攻修士課程修了。2002 年 (財) 電力中央研究 所ヒューマンファクター研究センター研究員。 現在, 同研究センター主任研究員としてエネル ギー事業のヒューマンファクター, 特に安全面 の研究に従事。

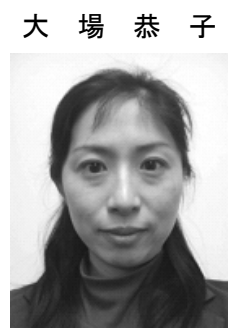

（非会員）1973 年生。1996 年多摩大学経営情 報学科卒業。1998 年慶應義塾大学大学院政策· メディア研究科修士課程修了。同年未来工学研 究所等の非常勤研究員。2002 年金沢工業大学科 学技術応用倫理研究所研究員。主として技術者 倫理教育の研究と実践に従事。日本原子力学会 倫理委員会副委員長。

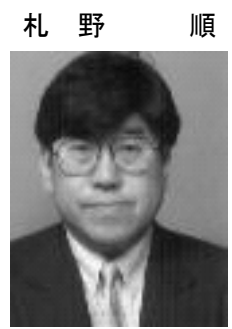

（非会員）1956 年生。1980 年国際基督教大学 教養学部理学科卒。1982 年同大学大学院教育学 研究科博士前期課程 (理科教授法) 修了。1990 年米国オクラホマ大学大学院科学史研究科博 士課程修了。オクラホマ大学 Research Assistant/ Teaching Assistant, スミソニアン研究所アメリ 力歴史博物館科学技術史部門 Graduate Fellow 等併任。1990 年金沢工業大学助教授。1994 年 教授。2004 年から科学技術応用倫理研究所所長 - 大学院工学研究科 専攻共通主任を兼務。哲学博士。 